\title{
ADVERSE EFFECT OF TOBACCO SMOKE ON RENAL DISEASE IN YOUNG HEALTHY MEDICAL STUDENTS: A CROSS SECTIONAL COMPARATIVE STUDY.
}

\footnotetext{
1. MBBS, MPH (Community Medicine)

Assistant Professor

Department of Community Medicine Mohi-ud-din Islamic Medical College,

Mirpur, Azad Kashmir.

2. MBBS, FCPS (Nephrologist) Assistant Professor Department of Nephrology $\mathrm{CMH}$ Kharian Medical College Pakistan.

3. MBBS, M Phil (Biochemistry) Senior Demonstrator Department of Biochemistry Mohi-ud-din Islamic Medical College,

Mirpur, Azad Kashmir.

4. MBBS, MBA, PhD (Pharmacology) Professor

Department of Pharmacology Mohi-ud-din Islamic Medical

College,

Mirpur, Azad Kashmir

5. MBBS, FCPS (Physiology) Professor

Department of Physiology

Mohi-ud-din Islamic Medical

College,

Mirpur, Azad Kashmir.
}

Correspondence Address:

Dr. Tahir Ahmad Munir

Department of Physiology

Muhi ud Din Islamic Medical College

Mirpur.

tahirahmadmunir19@gmail.com

Article received on:

23/08/2019

Accepted for publication:

$15 / 11 / 2019$

\section{INTORDUCTION}

Chronic kidney disease (CKD) is a global public health problem affecting all age groups. ${ }^{1}$ The mean global prevalence of CKD, $13.4 \%$ for stages $1-5$, is on increase and according to WHO, one of five adults with hypertension and one of three adults with diabetes have CKD. In 2010, 2.62 million patients were on dialysis worldwide and the figure will be doubled by 2030 . In spite of spending $>2-3 \%$ of the annual health-care budget, more than 969,000 annual deaths are resulted due to CKD globally. ${ }^{2}$ Africans, Americans, and South Asians are at high risk of developing $\mathrm{CKD}^{3}$; while in Pakistani population, new end-stage renal disease is $>100$ cases per

\author{
ljaz Ali ${ }^{1}$, Muhammad Irfan Khatak², Wajahat Ullah Khan ${ }^{3}$, Syed Hyder Raza ${ }^{4}$, Tahir Ahmad Munir
} Period: Fanuary-2018 to February-2019. Material \& Methods: 350 healthy medical students aged 17-19 years were divided into active, secondhand and unexposed to smoke on basis serum cotinine levels. The estimated GFR was measured by Modification of Diet in Rena (2012-guidelines. Results: Out of 350 participants, 49 were active and 126 were of noticed in $19 \%$ and albuminuria in $26.4 \%$ of the participants. The proteinuria in active smokers in comparison with unexposed showed a high OR-5.67-(95\%Cl-17.17-40.49), cotinine levels $>10 \mathrm{ng} / \mathrm{mL}$; OR-5.520-(95\%Cl-3.67-3.91), systolic BP >140 mmHg; OR-2.50-(95\%Cl- 0.1424.968); moderate to severely decreased eGFR, OR-2.478-(95\%Cl-0.124-4.391) and with high creatinine levels OR-4.300-(95\%Cl 2.432-7.603). The decreased eGFR showed Odds for obese OR-1.113(95\%Cl-2.391-5.197), active smokers OR-0.145(95\%Cl-0.029-0.721) and for systolic blood pressure >140 mmHg OR-6.892-(95\%Cl-1.414-2.235). Conclusion: Tobacco smoke exposure was associated with proteinuria and decreased eGFR effecting kidney functions in

Key words: $\quad$ Chronic Kidney Disease, Estimated Glomerular Filtration Rate, Healthy Person, Proteinuria, Smoking. sectional comparative study. Professional Med J 2020; 27(1):152-161. DOI: 10.29309/TPMJ/2020.27.1.4062 
(37\%) while the hypertension represents as third major cause $(9 \%) .{ }^{6}$ The studies have shown the role of cigarette smoke in CKD along with its wellknown decreased lung functions, delayed growth, increased risk of asthma, early atherosclerosis, neurocognitive defects, cancer, heavier smoking in adulthood and early childhood mortality. ${ }^{7,8}$ The outcomes of CKD include renal failure, increased risk of cardiovascular disease (hypertension, heart failure, heart attack) and premature death. ${ }^{9}$

The pathogenesis of cigarette smoke induced CKD is not yet completely understood but may involve oxidative stress, arteriolar changes, loss of renal epithelial cells and podocytes, inflammation, inflammatory and cellular responses, deposition of extracellular matrix, apoptosis and or metabolic dysregulation. 5,10

Studies are still lacking regarding association between CKD and active and secondhand smoke in generally healthy adolescents, because of vast heterogeneity in this age group, low incidence and less risk factors of CKD as hypertension and diabetes mellitus. ${ }^{11}$

The objective of this study is to see and compare the effect of active and secondhand smoke to unexposed smoke and renal functions in young healthy medical students.

\section{METHOD}

This cross sectional comparative study was conducted on 350 medical students of $1^{\text {st }}$ and $2^{\text {nd }}$ year MBBS at Mohi ud din Islamic Medical College Mirpur AJ\&K and CMH Kharian Medical College aged 17 to 19 years from February 2018 to February 2019, after taking written consent from participants and approval from the institutional ethical committee. The participants with primary kidney disease, diabetes mellitus, severe hypertension, and with sign symptoms of CKD were excluded from the study. Five $\mathrm{ml}$. blood sample was drawn under a-septic technique from the cubital vein to estimate serum cotinine and creatinine levels.

The serum cotinine (biomarker for tobacco exposure) levels were done on all students to assess tobacco smoke. The participants smoking actively or smoked only one cigarette or smoked one day last month or those with serum cotinine levels $>10 \mathrm{ng} / \mathrm{mL}$ whether reported as nonsmoker were taken as active smokers. The participants who reported living with person who smoke, regardless their cotinine level, or had cotinine levels $>0.05 \mathrm{ng} / \mathrm{mL}$ to $<10 \mathrm{ng} / \mathrm{mL}$ even not living with smoker, were labelled as secondhand smoke; while the participants with cotinine levels $<0.05 \mathrm{ng} / \mathrm{mL}$, not living with a smoker and not smoked since the last month were taken as unexposed to tobacco. ${ }^{12}$

The height and weight was measured (after removing jacket and shoes) to calculate BMl by dividing body weight in $\mathrm{kg}$ to height in $\mathrm{m} 2$; and the participants were categorized as normal, overweight, and obese according to the WHO recommendation, $\mathrm{BMl}<25 \mathrm{~kg} / \mathrm{m} 2 ; 25-30 \mathrm{~kg} / \mathrm{m}^{2}$; and $\mathrm{BMI} \geq 30 \mathrm{~kg} / \mathrm{m} 2$ respectively. Blood pressure was measured using mercury manometer in the sitting position after taking rest for 5 min or longer, and was graded into Normal $\mathrm{BP}=<120 /<80$ $\mathrm{mm} \mathrm{Hg}$; elevated BP $=120-129 /<80 \mathrm{~mm} \mathrm{Hg}$; stage 1 hypertension $=130-139$ or $80-89 \mathrm{~mm}$ $\mathrm{Hg}$, stage 2 hypertension $\geq 140$ or $\geq 90 \mathrm{~mm} \mathrm{Hg}$. The participants were labelled hypertensive after taking $\geq 2$ readings on $\geq 2$ occasions. ${ }^{13}$

To rate the CKD, we used the Kidney Disease: Improving Global Outcomes2012 (KDIGO 2012) criterion that takes presence of renal injury (albuminuria) and/or the decrease in eGFR. ${ }^{14}$ We used albuminuria as a marker of renal injury, and was considered as the ratio between the concentration of urinary albumin and creatinine, equal to or greater than 30 milligrams of albumin per gram of creatinine. The eGFR was estimated by the Cockcroft-Gault Modification of Diet in Renal Disease (MDRD) study equation. ${ }^{15}$ The calculated values below $60 \mathrm{ml} / \mathrm{min} / 1.73 \mathrm{~m} 2$ was taken as reduced. ${ }^{16}$

MDRD equation $=186 \times(\text { Creatinine/88.4 })^{-1.154} \mathrm{x}$ (Age $)^{-0.203} \times(0.742$ if female) $\times(1.210$ if black $)$. The serum creatinine was measured by coupled enzymatic assay and the corrected creatinine level was calculated by Corrected creatinine = - 
$0: 016(0: 9783 \times$ Creatinine $) .{ }^{17}$

The first urine sample was collected for measuring urinary creatinine and albumin levels to calculate proteinuria.

\section{DATA ANALYSIS}

Data were entered into a Microsoft Excel 2003 spreadsheet and analyzed, using the SPSS 18.0.1. The demographics and outcome variables were summarized using descriptive summary measures, expressed as percentage for categorical variables. Chi-Square test was used to compare the variables while Student ' $\mathrm{t}$ ' test was used for quantitative variables. Multivariate logistic regression used to identify the independent predictor variables. Adjusted matched odds ratio with its corresponding 95\% confidence interval was used and significance was taken at $P$-value less than 0.05 .

\section{RESULTS}

Table-I shows demographic, clinical and laboratory characteristics of adult participants according to smoking status. There are 350 participants, out of which 49 were active smoker, 126 secondhand smoker while 175 were not exposed to smoke. A statistically significant difference $(p<0.05)$ was noticed regarding BMI, creatinine, and eGFR when active smokers were compared to secondhand smoker, however, age, pulse, systolic and diastolic blood pressure were found to be non-significant $(p>0.05)$. The difference between active smoker and unexposed participants was also found statistically significant $(p<0.05)$ when age, pulse, BMI, creatinine, eGFR and systolic blood pressure were compared, while diastolic pressure was found to be nonsignificant. A same trend of significant difference $(p<0.05)$ was noticed for age, pulse, creatinine, and eGFR between the secondhand smoke and those who were not exposed to smoke, however, BMI systolic and diastolic blood pressure were found non-significant.

Table-Il shows comparison between male and female participants. A significant difference $(p<0.05)$ between the male and female participants was noticed when age, pulse, BMI, and creatinine were compared, however, the comparison was found to be non-significant $(p>0.05)$ when eGFR, systolic and diastolic pressure were compared.

Table-III showed tobacco smoke exposure status by participant characteristics. Most of active smokers (n-46) were male (93.9\%), overweight $(n-18,36.7 \%)$ or obese $(n-11,22.4 \%)$, with high creatinine levels ( $\mathrm{n}-36,73.5 \%)$, mild to moderate $(n-10,20.4 \%)$ to severe decreased eGFR (n-02, $4.1 \%)$, high systolic pressure $>140 \mathrm{mmHg}(\mathrm{n}-05$, $10 \%)$ and (n-04, >8\%) have diastolic pressure $>90 \mathrm{mmHg}$. All active smokers with their cotinine levels $>10 \mathrm{ng} / \mathrm{mL}$ showed proteins in their urine $(n-11,22.4 \%)$. The secondhand smokers (n-126) were also mostly male (n-102, 81\%), overweight (n-31, >24\%), obese (n-07, 5.6\%), showed high creatinine level $(n-28,22.2 \%)$, mild to moderate decreased eGFR (n- 07, 5.6\%), systolic pressure $>140 \mathrm{mmHg}(\mathrm{n}-03,2.4 \%)$ and diastolic pressure $>90 \mathrm{mmHg}$ (n-03, 2.4\%), however, urine positive for proteins was noticed in $(n-05,4 \%)$ of cases. Most of unexposed were female ( $n-148,84.6 \%)$ have normal BMI (n-108, 61.7\%), normal creatinine levels $(n-173,>98 \%)$ and eGFR (n$164,93.7 \%$ ). Most of the unexposed participants ( $\mathrm{n}-105,60 \%)$ were in normal range of systolic and diastolic blood pressure and did not show any proteins in urine.

Table-IV shows Multiple Logistic Regression with respect to proteinuria and low eGFR. The proteinuria in active smokers and secondhand smokers showed a significantly high OR, 5.67 (95\% Cl, 17.170 - 40.49) and OR, 3.25 (95\% Cl 3.67-3.98) respectively compared to unexposed. A same trend was seen with cotinine levels $>10$; OR, 5.520 (95\% Cl, 3.679 - 3.917) compared to non-exposed. A significant difference was noticed for systolic BP >140 mmHg; OR, 2.50 (95\% Cl 0.142 - 4.391); severely decreased GFR OR, 2.478 (95\% Cl $0.124-4.319)$ and for high creatinine levels OR 4.300 (95\% Cl $2.432-7.603)$ compared to non-exposed. The obese had no significant effects on development of proteinuria and showed a low odds ratio $0.653(95 \% \mathrm{Cl}-$ $0.073-.812)$. 
The Multiple logistic Regression analyses with moderate to severely decreased eGFR in the study groups showed a significant $(p<0.05)$ high OR of 6.892 (95\% Cl 1.414-2.235) with systolic blood pressure >140 mmHg; obese OR of 1.113 (95\% Cl, $2.391-5.197)$ and overweight OR 2.433 (95\% Cl, 2.497 - 2.908) participants. A same trend was also seen with active smokers OR, 0.145 $(95 \% \mathrm{Cl}, 0.029-0.721)$. Low GFR showed nonsignificant $(p<0.05)$ low OR of $0.498(95 \% \mathrm{Cl}$, $0.058-4.304$ ) with diastolic pressure $>90 \mathrm{mmHg}$, while an OR, 2.001 (95\% Cl, $0.816-4.905)$ with high creatinine, and an OR, $1.382(95 \% \mathrm{Cl}$, $0.323-5.913)$ with proteinuria in active smokers compared to unexposed.

Figure-1 shows the CKD prognosis considering categories of GFR and albuminuria. Out of 350 participants 321 (green - 91.7\%) were at low risk; 22 (purple $-6.3 \%$ ) at moderately increased risk; 06 (blue - 1.7\%) had high risk and 01 (red-0.3\%) were at very high risk of developing end-stage chronic kidney disease.

Green low risk

Purple moderate risk

Yellow high risk

Red very high risk.

\begin{tabular}{|c|c|c|c|c|c|c|}
\hline Variable & $\begin{array}{l}\text { Active Smoker } \\
\text { Group } 1(n-49)\end{array}$ & $\begin{array}{l}2^{\text {nd }} \text { hand smoker } \\
\text { Group } 2 \text { (n-126) }\end{array}$ & $\begin{array}{c}\text { Unexposed } \\
\text { Group } 3(n-175)\end{array}$ & $\begin{array}{l}\text { P-Value } \\
1 \& 2\end{array}$ & $\begin{array}{c}\text { P-Value } \\
1 \& 3\end{array}$ & $\begin{array}{c}\text { P-Value } \\
2 \& 3\end{array}$ \\
\hline Age & $20.24 \pm 1.47$ & $19.99 \pm 1.21$ & $19.84 \pm 1.03$ & 0.246 & 0.030 & 0.042 \\
\hline Pulse & $69.80 \pm 7.15$ & $71.25 \pm 10.59$ & $76.70 \pm 11.46$ & 0.379 & 0.000 & 0.000 \\
\hline BMI & $25.45 \pm 4.87$ & $23.00 \pm 3.89$ & $22.49 \pm 3.78$ & 0.001 & 0.000 & 0.255 \\
\hline Creatinine & $105.69 \pm 47.72$ & $74.86 \pm 26.86$ & $67.11 \pm 20.50$ & 0.000 & 0.000 & 0.005 \\
\hline eGFR & $75.57 \pm 20.67$ & $82.20 \pm 18.01$ & $89.77 \pm 16.04$ & 0.037 & 0.000 & 0.000 \\
\hline Systolic BP & $117.14 \pm 13.65$ & $113.65 \pm 10.20$ & $112.66 \pm 11.23$ & 0.067 & 0.020 & 0.435 \\
\hline Diastolic BP & $76.12 \pm 9.53$ & $74.76 \pm 8.64$ & $75.38 \pm 7.17$ & 0.365 & 0.558 & 0.494 \\
\hline
\end{tabular}

\begin{tabular}{|l|c|c|c|}
\hline \multicolumn{1}{|c|}{ Variable } & Male (N-175) & Female (N-175) & P-Value \\
\hline Age & $20.22 \pm 1.34$ & $19.69 \pm 0.915$ & 0.000 \\
\hline Pulse & $69.52 \pm 8.73$ & $78.02 \pm 11.45$ & 0.000 \\
\hline BMI & $24.09 \pm 4.37$ & $22.08 \pm 3.54$ & 0.000 \\
\hline Creatinine & $83.66 \pm 37.13$ & $66.94 \pm 19.04$ & 0.000 \\
\hline eGFR & $84.49 \pm 18.28$ & $85.62 \pm 18.08$ & 0.563 \\
\hline Systolic BP & $114.60 \pm 10.86$ & $112.69 \pm 11.71$ & 0.115 \\
\hline Diastolic BP & $75.07 \pm 8.90$ & $75.15 \pm 7.15$ & 0.658 \\
\hline
\end{tabular}

Table-II. Comparison between male and female participants regarding study variables. 


\begin{tabular}{|c|c|c|c|c|}
\hline Variable & $\begin{array}{l}\text { Active smoker } \\
\quad(n-49)\end{array}$ & $\begin{array}{l}\text { Secondhand smoker } \\
(n-126)\end{array}$ & $\begin{array}{l}\text { Unexposed } \\
(n-175)\end{array}$ & P-Value \\
\hline $\begin{array}{l}\text { Sex } \\
\text { Female }(n-175) \\
\text { Male }(n-175)\end{array}$ & $\begin{array}{c}03(6.1 \%) \\
46(93.9 \%)\end{array}$ & $\begin{array}{c}24(19.0 \%) \\
102(81.0 \%)\end{array}$ & $\begin{array}{l}148(84.6 \%) \\
27(15.4 \%)\end{array}$ & 0.000 \\
\hline $\begin{array}{l}\text { BMI } \\
\text { Normal }<25 \\
\text { Overweight 25-30 } \\
\text { Obese }>30\end{array}$ & $\begin{array}{l}20(40.8 \%) \\
18(36.7 \%) \\
11(22.4 \%)\end{array}$ & $\begin{array}{c}88(69.8 \%) \\
31(24.6 \%) \\
07(5.6 \%)\end{array}$ & $\begin{array}{c}108(61.7 \%) \\
54(30.9 \%) \\
13(7.4 \%)\end{array}$ & 0.001 \\
\hline $\begin{array}{l}\text { Creatinine }(\mathrm{ng} / \mathrm{mL}) \text {, } \\
\text { Normal } \\
\text { High }\end{array}$ & $\begin{array}{l}13(26.5 \%) \\
36(73.5 \%)\end{array}$ & $\begin{array}{l}98(77.8 \%) \\
28(22.2 \%)\end{array}$ & $\begin{array}{c}173(98.9 \%) \\
02(1.1 \%)\end{array}$ & 0.000 \\
\hline $\begin{array}{l}\text { eGFR }(\mathrm{mL} / \mathrm{min} \text { per } 1.73 \mathrm{~m} 2) \\
\text { Normal }(>90) \\
\text { Slightly decreased }(60-89) \\
\text { Mild to moderate decreased }(45-59) \\
\text { Moderate to severe }(30-45)\end{array}$ & $\begin{array}{c}14(28.6 \%) \\
23(46.9 \%) \\
10(20.4 \%) \\
02(4.1 \%)\end{array}$ & $\begin{array}{c}55(43.7 \%) \\
64(50.8 \%) \\
07(5.6 \%) \\
00(0 \%)\end{array}$ & $\begin{array}{c}164(93.7 \%) \\
11(6.3 \%) \\
00(0 \%) \\
00(0 \%)\end{array}$ & 0.000 \\
\hline $\begin{array}{l}\text { Systolic Blood pressure }(\mathrm{mmHg}) \\
<120 \\
120-129 \\
130-139 \\
>140\end{array}$ & $\begin{array}{c}31(63.3 \%) \\
09(18.4 \%) \\
04(8.2 \%) \\
05(10.2 \%)\end{array}$ & $\begin{array}{c}79(62.7 \%) \\
34(27.0 \%) \\
10(7.9 \%) \\
03(2.4 \%)\end{array}$ & $\begin{array}{c}105(60.0 \%) \\
55(31.4 \%) \\
12(6.9 \%) \\
03(1.7 \%)\end{array}$ & 0.066 \\
\hline $\begin{array}{l}\text { Diastolic Blood pressure }(\mathrm{mmHg}) \\
<80 \\
80-85 \\
86-90 \\
>90\end{array}$ & $\begin{array}{l}20(40.8 \%) \\
18(36.7 \%) \\
07(14.3 \%) \\
04(08.2 \%)\end{array}$ & $\begin{array}{c}50(39.7 \%) \\
51(40.5 \%) \\
22(17.5 \%) \\
03(2.4 \%)\end{array}$ & $\begin{array}{c}64(36.6 \%) \\
82(46.9 \%) \\
28(16.0 \%) \\
01(0.6 \%)\end{array}$ & 0.076 \\
\hline $\begin{array}{l}\text { Cotinine level }(\mathrm{ng} / \mathrm{mL}) \\
<0.05 \\
0.05-10 \\
>10\end{array}$ & $\begin{array}{c}0(0 \%) \\
0(0 \%) \\
49(100 \%)\end{array}$ & $\begin{array}{c}0(0 \%) \\
126(100 \%) \\
0(0 \%)\end{array}$ & $\begin{array}{c}175(100 \%) \\
0(0 \%) \\
0(0 \%)\end{array}$ & 0.000 \\
\hline $\begin{array}{l}\text { Urine protein } \\
<3 \mathrm{mg} \text { - } \mathrm{nmol} \\
3-30 \mathrm{mg}-\mathrm{nmol}\end{array}$ & $\begin{array}{l}38(77.6 \%) \\
11(22.4 \%)\end{array}$ & $\begin{array}{r}121(96 \%) \\
05(4 \%)\end{array}$ & $\begin{array}{c}175(100 \%) \\
00(0 \%)\end{array}$ & 0.000 \\
\hline
\end{tabular}

Table-III. Tobacco smoke exposure status by participant characteristics in Adolescents.

\section{DISCUSSION}

Considering the 2012 Kidney Disease: Improving Global Outcomes (KDIGO) guidelines for diagnosing and managing chronic kidney disease, our results showed $321(91.7 \%)$ participants at low risk of developing chronic kidney disease while $22(6.3 \%)$ participants at moderate risk for stage 1 and 2 chronic kidney disease mostly in patients with moderate albuminuria and mild to moderately decreased eGFR, 06 participants $(1.7 \%)$ showed high risk while only one $(0.3 \%)$ showed very high risk of developing CKD, however, none was found in stage 4 or 5 of renal failure. The main risk factors associated with CKD in our study were: male gender, active smoker with high cotinine levels, raised BMI and high systolic blood pressure. Globally, the prevalence of all CKD stages ranges between $8-16 \%$, as seen in our study. ${ }^{14}$ Certain studies showed a low CKD prevalence as these studies either consider the current CKD classification or included eGFR and/ or albuminuria in diagnosis of CKD..$^{18,19}$

Our results are consistent with a number of studies which showed raised arterial pressure with or without diabetes as an important and main risk factor of end-stage renal disease..$^{20,21}$ 


\begin{tabular}{|c|c|c|c|c|}
\hline Variables & Standard Error & Odds ratio & 95\% Confidence Interval & P-Value \\
\hline $\begin{array}{l}\text { Smoker } \\
\text { Unexposed } \\
\text { Secondhand } \\
\text { Active }\end{array}$ & $\begin{array}{l}0.653 \\
0.610\end{array}$ & $\begin{array}{l}3.251 \\
5.679\end{array}$ & $\begin{array}{c}3.67-3.987 \\
17.17-40.49\end{array}$ & $\begin{array}{l}0.000 \\
0.000\end{array}$ \\
\hline $\begin{array}{l}\text { Cotinine }(\mathrm{ng} / \mathrm{ml}) \\
<0.05 \\
0.05-10 \\
>10\end{array}$ & $\begin{array}{l}0.456 \\
0.571\end{array}$ & $\begin{array}{l}3.679 \\
5.520\end{array}$ & $\begin{array}{l}1.607-1.717 \\
3.679-3.917\end{array}$ & $\begin{array}{l}0.000 \\
0.000\end{array}$ \\
\hline $\begin{array}{l}\text { BMI } \\
25-30 \\
>30\end{array}$ & $\begin{array}{l}1.067 \\
1.115\end{array}$ & $\begin{array}{l}0.687 \\
0.653\end{array}$ & $\begin{array}{l}0.085-5.557 \\
0.073-5.812\end{array}$ & $\begin{array}{l}0.725 \\
0.703\end{array}$ \\
\hline Creatinine (high) & 0.291 & 4.300 & $2.432-7.603$ & 0.000 \\
\hline $\begin{array}{l}\text { eGFR } \\
\text { slightly decreased } \\
\text { Moderate } \\
\text { Severe }\end{array}$ & $\begin{array}{l}1.501 \\
1.476 \\
1.511\end{array}$ & $\begin{array}{l}5.250 \\
1.333 \\
2.478\end{array}$ & $\begin{array}{c}3.018-10.966 \\
0.850-2.510 \\
0.124-4.391\end{array}$ & $\begin{array}{l}0.007 \\
0.064 \\
0.562\end{array}$ \\
\hline $\begin{array}{l}\text { Systolic blood pressure } \\
\leq 120 \\
120-129 \\
130-139 \\
>140\end{array}$ & $\begin{array}{l}0.646 \\
0.677 \\
0.781\end{array}$ & $\begin{array}{l}1.855 \\
3.167 \\
2.500\end{array}$ & $\begin{array}{c}0.217-15.814 \\
0.300-3.374 \\
0.142-4.968\end{array}$ & $\begin{array}{l}0.014 \\
0.012 \\
0.049\end{array}$ \\
\hline $\begin{array}{l}\text { Diastolic BP } \\
\leq 80 \\
81-90 \\
>90\end{array}$ & $\begin{array}{l}0.840 \\
0.841 \\
0.879\end{array}$ & $\begin{array}{c}8.824 \\
11.613 \\
11.250\end{array}$ & $\begin{array}{l}1.700-45.803 \\
2.234-60.366 \\
2.010-62.973\end{array}$ & $\begin{array}{l}0.010 \\
0.004 \\
0.006\end{array}$ \\
\hline \multicolumn{5}{|c|}{ Multiple logistic regression analyses on association of variables with proteinuria in the study groups. } \\
\hline Variables & Standard error & Odds ratio & 95\% Confidence Interval & P-Value \\
\hline Proteinuria & 0.503 & 1.382 & $0.323-5.913$ & 0.008 \\
\hline Creatinine (high) & 0.457 & 2.001 & $0.816-4.905$ & 0.129 \\
\hline $\begin{array}{l}\mathrm{BMI}<25 \\
25-30 \\
>30\end{array}$ & $\begin{array}{l}1.162 \\
0.785\end{array}$ & $\begin{array}{l}2.433 \\
1.113\end{array}$ & $\begin{array}{l}2.497-2.908 \\
2.391-5.197\end{array}$ & $\begin{array}{l}0.000 \\
0.000\end{array}$ \\
\hline $\begin{array}{l}\text { Systolic blood pressure } \\
\leq 120 \\
120-129 \\
130-139 \\
>140\end{array}$ & $\begin{array}{l}1.339 \\
1.542 \\
0.109\end{array}$ & $\begin{array}{l}7.307 \\
6.123 \\
6.892\end{array}$ & $\begin{array}{l}2.831-6.054 \\
1.682-3.982 \\
1.414-2.235\end{array}$ & $\begin{array}{l}0.000 \\
0.000 \\
0.000\end{array}$ \\
\hline $\begin{array}{l}\text { Diastolic BP } \\
\leq 80 \\
81-90 \\
>90\end{array}$ & $\begin{array}{l}1.054 \\
1.039 \\
1.100\end{array}$ & $\begin{array}{l}0.734 \\
0.528 \\
0.498\end{array}$ & $\begin{array}{l}0.093-5.792 \\
0.069-4.047 \\
0.058-4.304\end{array}$ & $\begin{array}{l}0.769 \\
0.539 \\
0.527\end{array}$ \\
\hline $\begin{array}{l}\text { Smoker } \\
\text { Unexposed } \\
\text { Secondhand } \\
\text { Active }\end{array}$ & $\begin{array}{l}0.683 \\
0.819\end{array}$ & $\begin{array}{l}0.509 \\
0.145\end{array}$ & $\begin{array}{l}0.134-1.938 \\
0.029-0.721\end{array}$ & $\begin{array}{l}0.322 \\
0.018\end{array}$ \\
\hline
\end{tabular}

Table-IV. Multiple logistic regression analyses on association of variables with proteinuria in the study groups. 


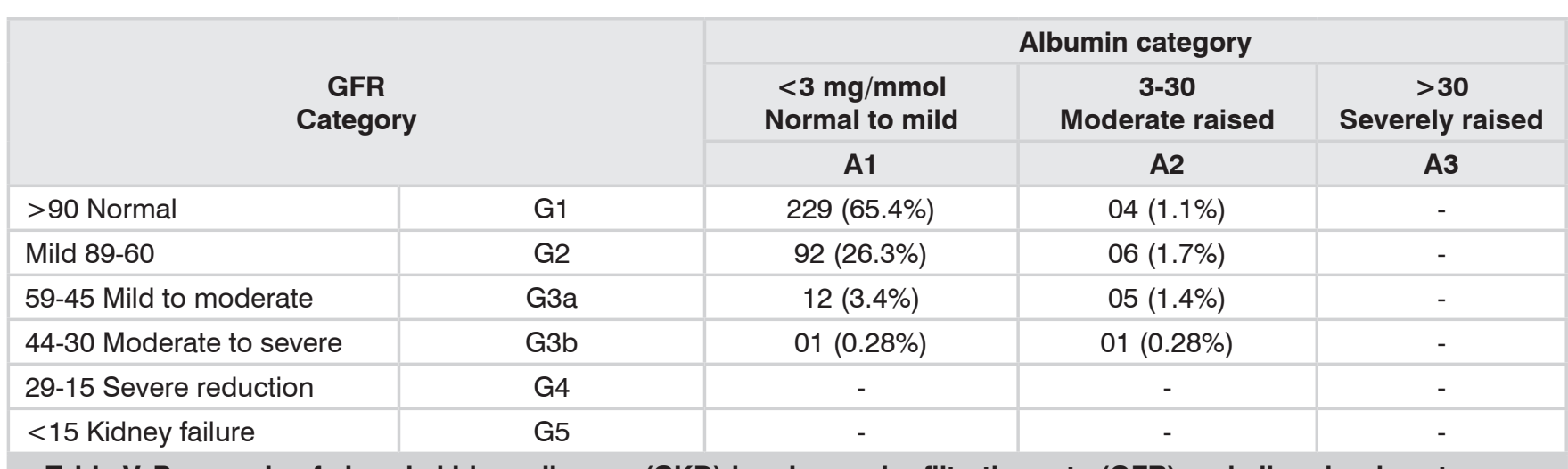

Table-V. Prognosis of chronic kidney disease (CKD) by glomerular filtration rate (GFR) and albuminuria category.

In the United States, approximately $26 \%$ of the people with hypertension have CKD; a study done in Mississippi22 showed that patients with more than one risk factors like hypertension, and diabetes have about twice the prevalence of low GFR and albuminuria compared to those with one factor, and declared that timely management of diabetes and hypertension decreases the rate of mortality due to CKD. The hypertensive renal disease depends on the degree of failure of the auto regulatory mechanisms that prevent BP elevation transmitted to the renal microvasculature and starting a vicious cycle of hypertension with a gradual decrease in GFR. ${ }^{10,20-22}$

In our results 19 (30.1\%) participants having eGFR less than $60 \mathrm{ml} / \mathrm{min} / 1.73 \mathrm{~m} 2$, and Multi logistic Regression analysis showed a significant association with albuminuria, raised $\mathrm{BMI}$, and systolic pressure $>140 \mathrm{mmHg}$. The National Health and Nutrition Examination Survey surveys of 1988-1994 and 1999-2004 (NHANES), after full adjustment of variables, found a prevalence of albuminuria and low GFR more strongly linked to hypertension. ${ }^{23}$ Both diabetes and high blood pressure can cause damage to the kidneys, decreased GFR and proteinuria. Our study participants with active smoking showed $(\mathrm{n}-12,24.5 \%)$ decreased eGFR $<60 \mathrm{ml} / \mathrm{min} / 1.73$ $\mathrm{m} 2$ and high percentage of albuminuria $(\mathrm{n}-11$, $22.4 \%$ ) compared to those with secondhand and unexposed to smoke. However, our results are not consistent with Erikson et $\mathrm{al}^{24}$ who showed that hypertension is not associated with decreased GFR, the reasons may be not considering effects of antihypertensive drugs on BP and measurement of GFR instead of calculating eGFR from creatinine.

The overweight and obesity, a modifiable risk factors for CKD, showed statistical significant association with decreased eGFR, however, it was not significantly related to proteinuria as seen in our study. The results are consistent with Josef et al. ${ }^{25}$ who reported a relationship of decreased eGFR and CKD in overweight and obese individuals. The kidney disorders related to obesity are considered to be secondary to glomerular hyper filtration, and release of inflammatory mediators from fat tissue. Albuminuria in obese persons is associated with large glomeruli, thickened basement membrane and podocyte distortion. The Boston University Framingham study (MESA) after 20 years of follow up, showed an association of BMI with risk of kidney disease and declared $20 \%$ increase of kidney disease with a single unit increase of BMI. ${ }^{26} \mathrm{~A}$ study from Copenhagen involving 20,000 women and 17,000 men aged 30-80 years showed 2.0-6.0 $\mathrm{mm} \mathrm{Hg}$ higher systolic and 1-3 $\mathrm{mm} \mathrm{Hg}$ raised diastolic pressure for each $10 \%$ increase in BMI. ${ }^{27}$

Active cigarette smoking showed strong and significant association with albuminuria (22.4\%), an important risk factor for progressive kidney disease. The Dialysis Mobidity and Mortality Study (DMMS) Wave 2 , showed $>40 \%$ patients on dialysis were smokers or secondhand smoker, but the association between smoking and decreased GFR, and albuminuria was non-significant. ${ }^{28}$ Many studies declared that cigarette smoke causes a decrease in GFR in diabetic patients with normal 
or near-normal renal function. ${ }^{9,11}$

In cigarette smoke there are increased serum cadmium and lead levels resulting glomerular dysfunction, while nicotine results increased incidence of micro-albuminuria leading to proteinuria and renal failure. These heavy toxins of cigarette smoke results renal damage by increased lipid peroxidation in the liver, decreased superoxide dismutase and increased catalase activity in the kidney, and stimulation of sympathetic nervous system with elevation in blood pressure. There occurs intra-renal vasoconstriction and effect on glomerular vessels which in turn stimulate renin-angiotensinaldosterone system, however, it may be a sign of glomerular hyper-filtration and early stage renal damage that is similar as observed in diabetic nephropathy. ${ }^{29,30}$

Our results are in agreement with a number of studies which showed that the participants with proteinuria have decreased eGFR. The KDIGO proposed risk classification showed that people with GFR $>60 \mathrm{ml} / \mathrm{min} / 1.73 \mathrm{~m} 2$, are taken healthy; but they are at risk of CKD if they have albuminuria and require early management indicating the significance of proteinuria in CKD progression. ${ }^{31}$ Yuka et al. ${ }^{32}$ showed that most smokers generally do not show any renal deterioration during their life, except a small population who show proteinuria. The process of albuminuria occurs through induction of chemokine in tubules, infiltration of inflammatory cells in the interstitium through activation of complement system and sustained fibrogenesis. ${ }^{33}$ Various screening programs based on proteinuria are done worldwide to find out and to reduce the dramatic increase in CKD prevalence, however, there is no evidence of benefit of these screening is seen.

\section{CONCLUSION}

Active and secondhand tobacco smoke causes an increased risk of developing proteinuria and decreased eGFR in most healthy adolescences. Copyright@ 15 Nov, 2019.

\section{REFERENCES}

1. Steven VL, Wim VB. Smoking and chronic kidney disease: Seeing the signs through the smoke? Nephrol Dial Transplant. 2017; 32:403-05.

2. The global burden of kidney disease and the sustainable development goals; Bulletin of the World Health Organization Genewa. WHO 2018; 96:414422D. doi: http://dx.doi.org/10.2471/BLT.17.206441.

3. Usman AK, Amit XG, Chirag RP, Steven GC. Prevention of chronic kidney disease and subsequent effect on mortality: A systematic review and meta-analysis. PLoS One. 2013; 8(8): e71784.doi:10.1371 / journal. Pone. 0071784.

4. Kifayat U, Ghias B, Imtiaz M, Kinza K, Farina K. Epidemiology of chronic kidney disease in a Pakistani population. Saudi J Kid Dis Trans 2015; 26(6):1307-10.

5. Ketteler M, Wanner C. Chronic kidney disease - Update 2018. Dtsch Med Wochenschr. 2018; 143(3):169-173. doi: 10.1055/s-0043-124831.

6. Nikolai C, Hodel ID, Ali H, Claudia P, Grace M, Irene M, et al. The epidemiology of chronic kidney disease and the association with non-communicable and communicable disorders in a population of subSaharan Africa. PLoS ONE 2018;13(10): e0205326.

7. Leonberg AK, Rudnick MR. Tobacco Use: A chronic kidney disease accelerant. Am J Nephrol 2017; 46:257-9.

8. Jia X, Lin W, Zhiheng M, Liping Z, Ying W, Yachan G, et al. Cigarette smoking and chronic kidney disease in the general population: A systematic review and meta-analysis of prospective cohort studies. Nephrol Dial Transplant 2017; 32: 475-87.

9. Evan T, Aarushi B, Marta N, Istvan M. Patient-reported outcomes in patients with chronic kidney disease and kidney transplant-Part 1. Front Med (Lausanne) 2017; 4:254-9.

10. Yasuhiko T. Pathogenesis and Treatment of Chronic Kidney Disease: A Review of Our Recent Basic and Clinical Data. Kidney Blood Press Res 2014; 39:45089.

11. Jong HJ, Young SJ, Youn KK, Su YJ, Seohyun P, Chang YY, et al. Secondhand smoke and CKD. Clin J Am Soc Nephrol 2019; 14 (4): 515-22.

12. Andres D, Paula M, Astrid G, Diego F, Carlos A, Adolfo $C$, et al. Accuracy of cotinine serum test to detect the smoking habit and its association with periodontal disease in a multicenter study. Med Oral Patol Oral Cir Bucal 2017; 22(4): e425-e31. 
13. Whelton PK, Carey RM, Aronow WS, Melvyn R. Guideline for the prevention, detection, evaluation, and management of high blood pressure in adults: A Report of the American College of Cardiology/ American Heart Association Task Force on Clinical Practice Guidelines. J Am Coll Cardiol 2018; 71:e127-e248.

14. Adeera L, Paul E. Summary of KDIGO 2012 CKD guideline: behind the scenes, need for guidance, and a framework for moving forward. Kidney Int 2013; 85:49-61; doi:10.1038/ki.2013.444;

15. Miller WG, Graham RD. Estimated glomerular filtration rate; Laboratory implementation and current global status. Adv Chronic Kidney Dis. 2018; 25(1):7-13.

16. Rossini $B$, Jean $M$, Cecilé $C$, Otto $S$, Jean $F$, Jack $F$. Estimating glomerular filtration rate: Cockcroftgault and modification of diet in renal disease formulas compared to renal inulin clearance. Clin J Am Soc Nephrol 2009; 4(5): 899-906.doi: 10.2215/ CJN.05371008.

17. Anne B, Nils K, Etienne C, Laurence P, Jean S, Pierre D. Serum creatinine: Advantages and pitfalls. J Lab Precis Med 2018;3:71-8.

18. Esther GE, Lauren FL, Virginia MW, Jeffrey JF, Ana NA. Kidney function and tobacco smoke exposure in US adolescents. Pediatrics 2013;131:e1415-e23.

19. Edna R, Aline CP, Guilherme BA, lessandra VN, Fernanda KM, Sandro RB, et al. Prevalence of chronic renal disease in adults attended by the family health strategy. J. Bras. Nefrol 2016; 38: 22-30. doi: 10.5935/0101-2800.20160005.

20. Emmy K, Bell L, Gao S, Judd S, Glasser W, Clellan O. Blood pressure indexes and end-stage renal disease risk in adults with chronic kidney disease. Am J Hypertens 2012; 25:(7), 789-96.

21. Michael EH, Jussara MC, Alexandre AS, Luis AJ, Zhen WI, John EH, et al. Obesity, hypertension, and chronic kidney disease. Int $\mathrm{J}$ Nephrol Renovasc Dis 2014; 7:75-88.

22. Daniel M, Charles E, Feng L, Tanushree B, Jennifer L, Bragg $G$, et al. Trends in prevalence of chronic kidney disease in the United States. Ann Intern Med 2016; 165(7): 473-81.

23. Elizabeth S, Jane M, Lesley A, Frederick V, David A, Andrew $S$, et al. Calibration of Serum Creatinine in the National Health and Nutrition Examination Surveys (NHANES) 1988-1994, 1999-2004. Am J Kidney Dis 2007; 50:918-26.
24. Eriksen BO, Stefansson VT, Jenssen TG, Mathisen UD, Schei J, Solbu MD, et al. Elevated blood pressure is not associated with accelerated glomerular filtration rate decline in the general non-diabetic middle-aged population. Kidney Int. 2016; 90(2):40410.

25. Josef C, Tanvir C, Kunihiro M, Yingying S, Shoshana $\mathrm{H}$, Lawrence $\mathrm{J}$. Decline in estimated glomerular filtration rate and subsequent risk of end-stage renal disease and mortality. JAMA 2014; 311(24): 2518-31.

26. Anna M, Ronit K, Michael G, Joachim H, lan H, Mark J. Association of obesity and kidney function decline among non-diabetic adults with eGFR > $60 \mathrm{ml} /$ $\mathrm{min} / 1.73 \mathrm{~m}^{2}$ : Results from the Multi-Ethnic Study of Atherosclerosis (MESA). Open $\mathrm{J}$ Endocr Metab Dis 2013; 3(2):103-12.

27. Jostein H, Turid L, Aage T, Oddgeir L, Erik S, Kristian $\mathrm{M}$, et al. Blood pressure changes during 22-year of follow-up in large general population - the HUNT Study, Norway. BMC Cardiovasc Disord 2016; 16: 94e.

28. Suzanne MB, Yimei LF, Perry WE, Joel DG, Harold IF. Association of alternative approaches to normalizing peritoneal dialysis clearance with mortality and technique failure: A retrospective analysis using the Umited States Renal Data System Dialysis and Mortality Status, WAVE 2. Perit Dial Int 2017 1-2; 37(1): 85-93.

29. Halimi J, Albert M. Renal effects of smoking: Potential mechanisms and perspectives. Nephrol Dial Transplant 2000; 15(7):938-40.

30. Yoo KL, Michael RR. Tobacco Use: A chronic kidney disease accelerant Amanda. Am J Nephrol 2017;46:257-9 DOI: 10.1159/000481209

31. Sparrow HG, Swan JT, Moore LW, Gaber AO, Suki WN. Disparate outcomes observed within kidney disease. Improving global outcomes (KIDGO) acute kidney injury stage-1. Kidney Int 2019; 95(4):905-13. doi: 10.1016/j.kint.2018.11.030.

32. Yuka N, Masao I, Yuichi Y, Ryumon H, Hitoshi Y, Masaru $M$, et al. The effects of continuing and discontinuing smoking on the development of chronic kidney disease (CKD) in the healthy middle-aged working population in Japan. Environ Health Prev Med 2013; 18(1):24-32.

33. Paolo C, Giuseppe R. Pathophysiology of proteinuria and its value as an outcome measure in chronic kidney disease. Br J Clin Pharmacol 2013; 76(4): 51623. 


\begin{tabular}{|c|c|c|c|}
\hline \multicolumn{4}{|c|}{ AUTHORSHIP AND CONTRIBUTION DECLARATION } \\
\hline Sr. \# & Author(s) Full Name & Contribution to the paper & Author(s) Signature \\
\hline 1 & Ijaz Ali & $\begin{array}{l}\text { Study design, Statistical } \\
\text { analysis, Data interpretation. }\end{array}$ & \\
\hline 2 & Muhammad Irfan Khatak & Principal investigator. & \\
\hline 3 & Wajahat Ullah Khan & $\begin{array}{l}\text { Sample collection, Writing } \\
\text { correction. }\end{array}$ & \\
\hline 4 & Syed Hyder Raza & $\begin{array}{l}\text { Writing support, data } \\
\text { interpretation. }\end{array}$ & \\
\hline 5 & & $\begin{array}{l}\text { Data collection and } \\
\text { Corresponding author. }\end{array}$ & \\
\hline
\end{tabular}

